\title{
How Does the Brain Implement Adaptive Decision Making to Eat?
}

\author{
Valérie Compan, ${ }^{1}$ B. Timothy Walsh, ${ }^{2}$ Walter Kaye, ${ }^{3}$ and Allan Geliebter ${ }^{4,5}$ \\ ${ }^{1}$ Nîmes University, Place Gabriel Peri, Carmes, 30021 Nîmes, France, ${ }^{2}$ New York State Psychiatric Institute/Columbia University Medical Center, New York, \\ New York 10032, ${ }^{3}$ Eating Disorder Treatment and Research Program, Department of Psychiatry, University of California, La Jolla, California 92037, \\ ${ }^{4}$ Department of Psychiatry, Montana Sinai School of Medicine, New York, New York 10029, and ${ }^{5}$ Department of Psychology, Touro College and University \\ System, New York, New York 10023
}

Adaptive decision making to eat is crucial for survival, but in anorexia nervosa, the brain persistently supports reduced food intake despite a growing need for energy. How the brain persists in reducing food intake, sometimes even to the point of death and despite the evolution of multiple mechanisms to ensure survival by governing adaptive eating behaviors, remains mysterious. Neural substrates belong to the reward-habit system, which could differ among the eating disorders. The present review provides an overview of neural circuitry of restrictive food choice, binge eating, and the contribution of specific serotonin receptors. One possibility is that restrictive food intake critically engages goal-directed (decision making) systems and "habit," supporting the view that persistent caloric restriction mimics some aspects of addiction to drugs of abuse.

Key words: anorexia; decision making; dependence; reward; obesity; serotonin

\section{Significance Statement}

An improved understanding of the neural basis of eating disorders is a timely challenge because these disorders can be deadly. Up to 70 million of people in the world suffer from eating disorders. Anorexia nervosa affects 1-4\% of women in United States and is the first cause of death among adolescents in Europe. Studies relying on animal models suggest that decision making to eat (or not) can prevail over actual energy requirements due to emotional disturbances resulting in abnormal habitual behavior, mimicking dependence. These recent studies provide a foundation for developing more specific and effective interventions for these disorders.

\section{Introduction}

Feeding behavior results from a combination of factors from the internal and external environments and is a typical motivated behavior. Feeding behavior maintains the body weight of an organism to a threshold specific to one's species (as for temperature; Kupfermann, 1991). From this comes the complexity: food intake depends on homeostatic rules and also on other internal states, motivational states also called "drives" (Kupfermann, 1991). Motivation is expressed when it triggers goal-directed behavior. When individuals feel hungry, they are motivated to ob-

\footnotetext{
Received July 8, 2015; revised Aug. 31, 2015; accepted Sept. 15, 2015.

This work was supported by the Agence Nationale de la Recherche (ANR-09-MNPS-024-01: SERFEED), the ADOR Foundation (Anorexia, Dependence, Obesity, Receptors University Foundation, Nîmes University), National Institutes of Health (Grant NIDDK080153; 746), National Institute of Mental Health (Grant MH79397, R01MH042984), the Global Foundation for Eating Disorders, and the Price Foundation.

The authors declare no competing financial interests.

Correspondence should be addressed to Dr. Valérie Compan, Nîmes University, Place Gabriel Peri, Carmes, 30021 Nîmes, France. E-mail: valerie.compan@unimes.fr.

DOI:10.1523/JNEUROSCI.2602-15.2015

Copyright $\odot 2015$ the authors $\quad 0270-6474 / 15 / 3513868-11 \$ 15.00 / 0$
}

tain food. Feeling hungry then translates into the demand for energy. Hunger impels the organism to display goal-directed behavior to seek and consume foods and thus survive. Individuals do not make the decision to feel hungry, but can decide to satisfy or not satisfy hunger.

For some individuals, eating behavior can be chronically disordered and can include persistent food restriction and/or excessive intake despite negative consequences, suggesting disturbances of motivation and of goal-directed behavior (decision making). Food is a basic primary reward, requiring motivation to obtain it ("wanting"; Hoebel, 1997). Some investigators suggest that excessive consumption of foods, regardless of whether it is associated with obesity (Corwin et al., 2011), mimics addiction (Avena, 2010). However, whether binge eating represents a kind of addiction remains unclear (Corwin, 2011).

Common molecular mechanisms also exist between anorexia and addiction. Indeed, drugs of abuse (e.g., cocaine, amphetamine) trigger adaptive responses including an increased activity of the cyclic adenosine monophosphate (cAMP)/protein kinase A (PKA) signaling pathway in the nucleus accumbens (NAc), a 
critical brain structure of the reward system (Koob and Nestler, 1997; Nestler, 2005; Chen et al., 2009). The resultant phosphorylation of the cAMP-response element binding protein (CREB) dampens rewarding effects. Therefore, the sensitivity to subsequent drug exposures decreases (tolerance) with increased activity of reward pathways (dependence) to the point that drugs removal triggers depressive states (Nestler, 2004). Stimulation of the cAMP/PKA/cocaine- and amphetamine-regulated transcript (CART) pathway in the NAc after local stimulation of the serotonin (5-hydroxytryptamine, 5-HT) 4 receptors $\left(5-\mathrm{HTR}_{4}\right)$ provokes anorexia (Jean et al., 2007). This pathway is also involved in anorexia induced by the 3,4- $\mathrm{N}$-methylenedioxymethamphetamine, the psychogenic compound of ecstasy (Jean et al., 2007). The ability of cocaine-addiction-related animal models (Rocha et al., 1998) to eat less despite an early period ( $3 \mathrm{~d}$ ) of deprivation further depends on a gain-of-function of 5 - $\mathrm{HTR}_{4}$ with CART overexpression in the NAc (Jean et al., 2012b). Considering the involvement of CART in motivational properties of cocaine (Couceyro et al., 2005; Rogge et al., 2009), these findings evidence a "shared neural signal foul-up" between drug dependence and anorexia that is consistent with deficits in neural networks underlying addiction in patients with anorexia nervosa (Kaye et al., 2009; Nestler, 2013). The rewarding effect of anorexia has been described in humans at the onset of anorexia nervosa symptoms (Brockmeyer et al., 2013). Indeed, the brain can implement food restriction until death as the result of maladaptive decision making. Because the prospect of receipt of a positive reward is capable of inducing risky, and potentially lethal behavior, potential neural deficits that restrict food intake to a lethal point could be included in those of dependence, which requires further testing.

Examination of the activity of neural centers involved in the recognition of rewards and the development of habits is therefore relevant (Walsh, 2013). A recent report described goaldirected decision making as a complex process and argued that reward-based decisions depend on the habit and goal-oriented systems (Solway and Botvinick, 2012). The habit system "stores" stimulus-response associations based on past rewards and the goal-oriented system selects one action by anticipating the positive and negative outcomes (Solway and Botvinick, 2012). Because "addiction is a form of learning and relapse is a persistent memory of the drug experience" (Wikler, 1961), feeding behavior appears to result from integrated activity of an autonomous and voluntary nervous systems informed by the sensory nervous system of external environment states. However, excessive and restrictive intake of food can prevail over homeostatic rules. Studying neural substrates of feeding behavior is therefore critical to better understand how neural systems interact to make adaptive decisions to eat or not in the face of environmental changes (i.e., stressors). Indeed, responses to stress include reduced food intake despite requirements for energy (Stone et al., 1984; Shibasaki et al., 1988; Shimizu et al., 1989; Grignaschi et al., 1993; Haleem et al., 1998), macronutrient selection (Wang, 2002), and increased consumption of food (Rowland and Antelman, 1976; for review, see Morley et al., 1983).

Our understanding of brain functions often comes from clinical descriptions of symptoms in humans. Indeed, symptoms of anorexia nervosa make visible a likely "crosstalk" between different cerebral structures. We will use "anorexia" instead of "anorexia-like behavior" for animals. Animals display anorexia that is operationally defined as reduced food intake despite the physiological energy demand; that is, after partial or total food deprivation (Jean et al., 2012b). Patients with anorexia nervosa can reduce food intake and even starve to death and often display emaciation, amenorrhea, motor hyperactivity or "overexercise" (Beumont et al., 1994; Casper, 2006), anxiety (Godart et al., 2000; Kaye et al., 2004), harm avoidance [excluding possible harm due to anorexia (Fassino et al., 2002)], perfectionism (Friederich and Herzog, 2011), obsessionality (Anderluh et al., 2003; van den Heuvel et al., 2005), and depression (Casper, 1998). Individuals suffering from anorexia nervosa can also struggle with bulimia (i.e., overeating with purging). The symptomatology of anorexia nervosa is complex, especially when food restriction alternates with bulimia that differs from binge eating (Corwin et al., 2011). Binge eating involves uncontrollable consumption of large amounts of food, but is not followed by food purging. Understanding anorexia is a major challenge because restrictive feeding aggravates numerous diseases and is the first cause of death of adolescents in Europe (Papadopoulos et al., 2009). Indeed, personality traits (anxiety, harm avoidance, obsession, perfectionism) often occur in childhood before the onset of eating disorders and likely implement biological predisposition and account for $\sim 50-80 \%$ of the risk of developing eating disorders (Bulik et al., 2006; Kaye et al., 2009).

In this mini-review, we will consider first the most known molecular mechanisms that have been observed in the hypothalamus and the NAc, two respective critical brain areas related to the autonomic and voluntary nervous system. In addition, although numerous peptidergic systems are involved, we will focus on serotonergic systems that are also known to have a prime role in survival mechanisms because of their clear involvement in adaptive responses to stress, emotional states, and feeding behavior. Mainly based on recent results, we suggest that voluntary control processes in the nervous system (underlying decision and motivation) can be modified to prevail over cerebral autonomous control of hunger, compromising survival. To better understand how the brain implements adaptive decision making to eat, we will consider the neural circuitry involved in persistent restrictive food choice, consistently with the fact that an altered balance between reward and inhibition may favor extremes in food intake. At a molecular level of analyses, we will then describe particular mechanisms in the NAc that could underlie the switch from undereating to overeating in animal models. Finally, we will show that these brain activities depend on environmental factors transmitted via the sensory system (e.g., individuals with obesity vs lean) show differential neural responses to visual and auditory food cues of high- and low-palatability foods.

\section{Critical brain areas of the CNS control food intake: autonomous versus voluntary control}

The main area of current research remains the delineation of subcircuits in the hypothalamus that regulate the autonomic nervous system and control energy homeostasis. In summary (Schwartz et al., 2000), hypothalamic neurons in the arcuate nucleus coexpress either neuropeptide (NPY) and agouti related-peptide (AgRp) or CART and POMC and their respective activation increases and decreases food intake upon the influence of numerous messengers, including those secreted by peripheral organs (leptin, ghrelin, orexin, etc.). In turn, AgRp-containing neurons in the arcuate nucleus mainly target neurons in the paraventricular nucleus that express melanocortin 4 receptors (MCR4; Garfield et al., 2015). Stimulation of the MCR4 decreases food intake (Adan and Kas, 2003; Lubrano-Berthelier et al., 2003; Srinivasan et al., 2004; Kim et al., 2008).

In parallel, accumulating evidence shows a critical influence of 5-HT on food intake (for review, see Compan, 2013). In the 


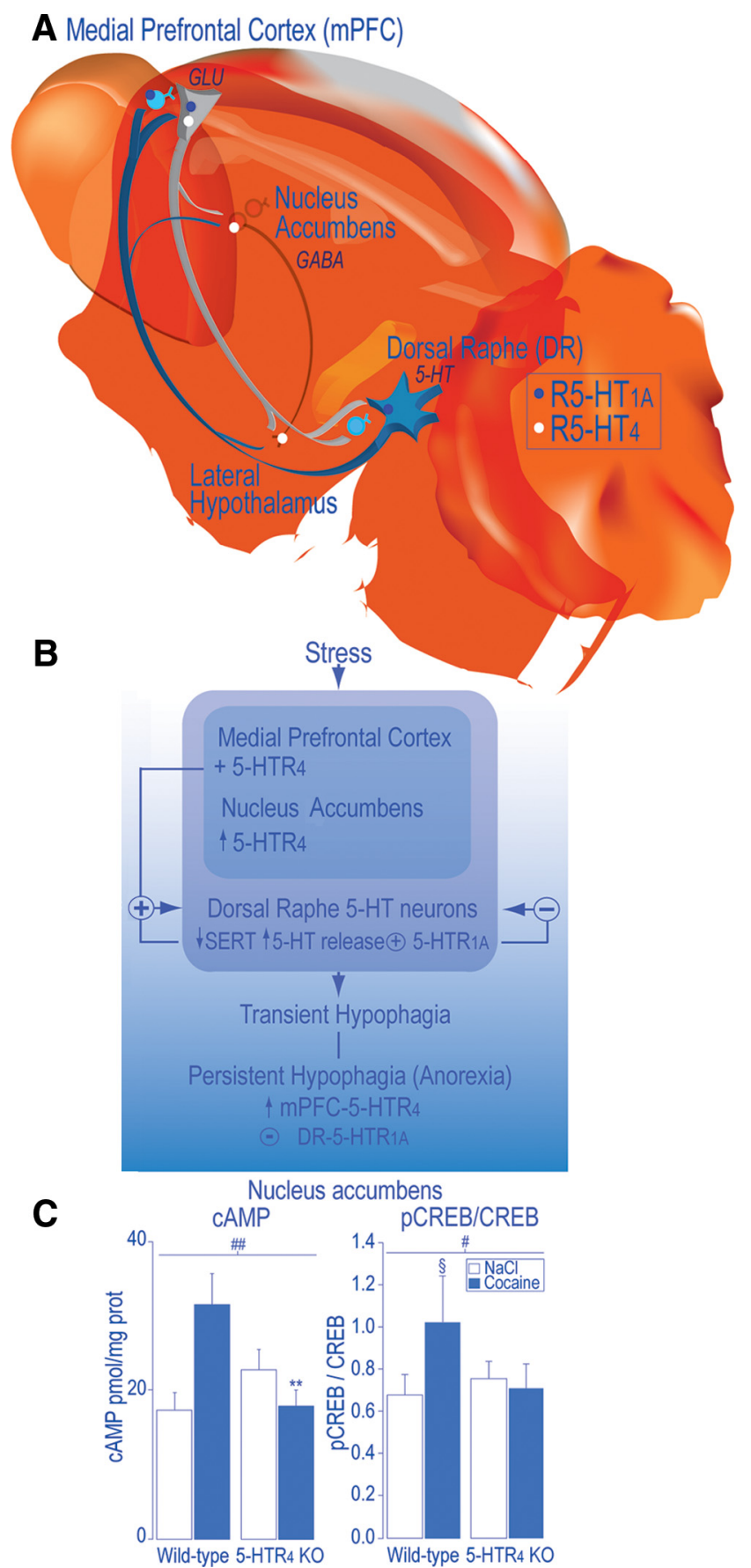

Figure 1. A working hypothesis: decision making to eat could partly depend on neural pathways concerned with dealing with stress. $A$, Efferent neurons of the mPFC mainly target the DR (Sesack et al., 1989; Peyron et al., 1998; Vertes, 2004) and contain glutamate (GLU) (Lee et al., 2003). With regard to the reciprocal descending projections, $5-\mathrm{HT}$ neurons in the mPFC mainly arise from the DR and send axon collaterals to the NAc (Van Bockstaele et al., 1993). In the mPFC, $60 \%$ of pyramidal efferent neurons express both $5-\mathrm{HTR}_{4}$ and $5-\mathrm{HTR}_{1 \mathrm{~A}}$ mRNA (Feng et al., 2001). In the mPFC, $5-\mathrm{HTR}_{4}$ mRNA are mainly expressed by GLU-expressing efferent neurons (PenasCazorla and Vilaro, 2014). In the NAc, 5-HTR ${ }_{4}$ are localized on GABA-expressing efferent neurons to the lateral hypothalamus (Jean et al., 2007). In the mPFC, the 5-HTR 1 is localized, in the $\mathrm{mPFC}$, in glutamatergic pyramidal efferent, local GABA-expressing interneurons (Czyrak et al., 2003; Amargós-Bosch et al., 2004; Santana et al., 2004) and on 5-HT terminals and, in the DR, on DR 5-HT neurons (Miquel et al., 1992; Pompeiano et al., 1992). B, From the mPFC, 5 -HTR exert $^{2}$ a tonic positive influence on the firing activity of DR 5 -HT neurons in rodents (Lucas and Debonnel, 2002; Lucas et al., 2005; (onductier et al., 2006). From the DR and mPFC, 5-HTR 1 exert a negative feedback on DR 5-HT neurons (Sprouse and Aghajanian, 1987; Haj-Dahmane et al., 1991; Bortolozzi et al., 2004). We found that mPFC 5 -HTR 4 overexpression induced decreases in the levels of plasma membrane 5-HT transporter (SERT) and increases in 5-HT release, which hypothalamus, stimulation of the $5-\mathrm{HT}_{2 \mathrm{C}}$ receptors $\left(5-\mathrm{HTR}_{2 \mathrm{C}}\right)$, likely located on CART/POMC neurons, induced increases in the $\alpha$-melanocyte-stimulating hormone release and reduced food intake (Heisler et al., 2002). Consistently, lorcaserin, a 5-HTR $2 \mathrm{C}$ agonist, appears effective in reducing obesity and possibly abuse of substances in humans (Higgins et al., 2013; Howell and Cunningham, 2015), in agreement with an enhanced cocaine selfadministration in the 5- $\mathrm{HTR}_{2 \mathrm{C}}$ knock-out $(\mathrm{KO})$ mice (Rocha et al., 2002). Stimulating $5-\mathrm{HTR}_{1 \mathrm{~B}}$ in the hypothalamus also reduces food intake and may favor the inhibitory control of 5-HTR $2 \mathrm{C}$ (Doslikova et al., 2013). In contrast, activation of the $5-\mathrm{HTR}_{1 \mathrm{~A}}$ and $5-\mathrm{HTR}_{2 \mathrm{~B}}$ in the arcuate nucleus, expressed by POMC neurons, increases food intake (Yadav et al., 2009; Yadav et al., 2011). Nonetheless, $5-\mathrm{HTR}_{1 \mathrm{~A}} / 5-\mathrm{HTR}_{2 \mathrm{~B}}$ could be "modulators" between two "anorectic factors," leptin and MCR4 in the hypothalamus. Leptin inhibits 5-HT cells activity in the brainstem and thus reduces the inhibitory control of $5-\mathrm{HTR}_{1 \mathrm{~A}}$ on MCR4 mRNA expression in the hypothalamus, resulting in reduced food intake (Kumar et al., 2010).

Autonomous control of food intake appears to depend largely on the hypothalamus, including likely important downstream pathways between the parabrachial nucleus and the central nucleus of amydgdala (Carter et al., 2013), but the involvement of the voluntary system, including the NAc and medial prefrontal cortex (mFPC), is less clear. However, the critical role of the NAc and $\mathrm{mPFC}$ in motivation and goal-directed behavior suggests that both structures could trigger increased or decreased intake of foods that could override actual energy needs (in opposition to the hypothalamus).

Analyses have been mainly conducted in the NAc and show that, in addition to the hypothalamus, peptides influence food intake (e.g., CART, NPY, galanin, melanocortins, glucagon-like peptide, opioids; Zhang and Kelley, 1997; Jean et al., 2007; Woolley et al., 2007; Picciotto, 2008; Pandit et al., 2011; Reddy et al., 2014; van den Heuvel et al., 2015). In addition, over the last few years, dopamine has been often related to "food addiction" and obesity (for review, see Salamone and Correa, 2013), whereas a 5-HT-dependent addictive pathway in the NAc (Jean et al., 2007) involving a $5-\mathrm{HTR}_{4}$ and $5-\mathrm{HTR}_{1 \mathrm{~B}}$ interrelation supports anorexia (Jean et al., 2012b). Nonetheless, and as observed in the hypothalamus for different 5-HT receptor subtypes, stimulation of the 5- $\mathrm{HTR}_{6}$ provokes overeating (Pratt et al., 2009).

A key question is what are the neural substrates that initiate the transition from transient to persistent restrictive food intake; that is, those that would abnormally favor an "early decision making" to not eat. We suspected impaired activity of a network governing goal-directed behavior (decision making), the ascend-

activates DR 5-HTR ${ }_{1 \mathrm{~A}}$ that prevent the transition from a transient to a sustained hypophagia ("early anorexia"), introducing anorexia as an antidepressant (5-HT accumulation resulting from 5-HTR ${ }_{1 \mathrm{~A}}$ desensitization and SERT reduction; Jean et al., 2012a, unpublished data). In addition, stimulation of $5-\mathrm{HTR}_{4}$ in the NAc enhanced the activity of an addictive signaling pathway (CAMP/PKA/CART), which provokes anorexia and motor hyperactivity (Jean et al., $2007,2012 \mathrm{~b}$ ), suggesting that neural substrates of anorexia are included in those of dependence. C, Consistently, acute intraperitoneal administration of cocaine $(30 \mathrm{mg} / \mathrm{kg})$ failed to increase, in the NAc, CAMP levels and pCREB/CREB ratio, in 5-HTR $\mathrm{K}_{4} \mathrm{KO}$ compared with wild-type mice. Data are means $\pm \mathrm{SEM}, n=5-8$ mice of both genotypes per each group. A significant treatment effect is noted: $\S p<0.05, \S \S p<0.01$ compared with $\mathrm{NaCl}$, a genotype effect $\left({ }^{*} p<\right.$ 0.05 ) and genotype $\times$ treatment interaction, $\# p<0.05$, \#\# $p<0.01$ after significant twoway ANOVA. We posit that decreased activity of the mPFC-5-HTR (among many other factors) could favor a subcortical influence; that is, an autonomous control without adaptive decisional control regardless of the requirement for energy (Compan, 2013). 


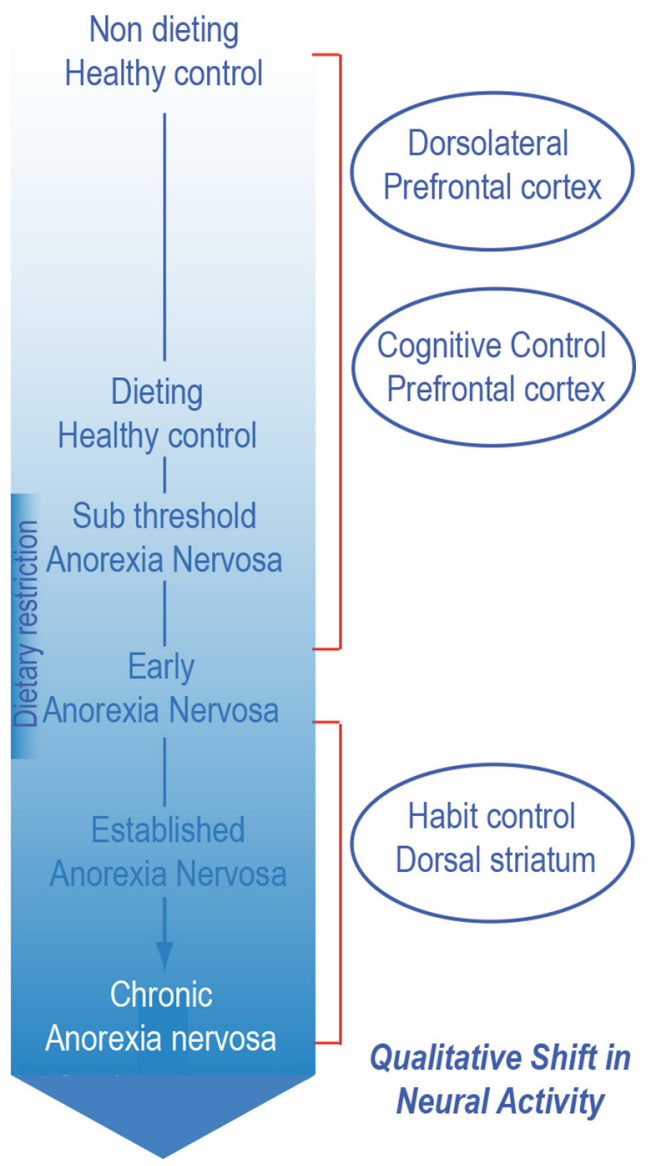

Figure 2. Reproduced with permission from Steinglass and Foerde (2015) (and see Foerde et al., 2015).

ing serotoninergic inputs from the dorsal raphe nucleus to the mPFC for several reasons: (1) this network supports an adaptive "decision" to avoid adverse effect of stress and then depressive states (Amat et al., 2005; Robbins, 2005; Euston et al., 2012); (2) eating disorders are stress related (for review, see Hardaway et al., 2015); and (3) eating disorders are often associated with depression (Micali et al., 2015). Our working hypotheses are schematized in Figure 1 (Jean et al., 2012a, unpublished data), introducing the idea that processes within the voluntary nervous system (underlying decision, motivation) could be modified to prevail over a cerebral autonomous control of hunger, compromising survival. This study suggests a primary mechanism that could support the onset of a persistent hypophagia ("an early anorexia") whereby individuals shift from adaptive to persistent maladaptive food choice as in anorexia nervosa (Walsh, 2013; Fig. 2).

\section{Neural circuitry involved in persistent restrictive food choice}

One of the major unanswered questions about anorexia nervosa is how to account for its persistence. The salient behavioral feature of anorexia nervosa is the avoidance of high-fat foods (Walsh, 2011). This pattern of behavior is consistent across individuals and not difficult to measure objectively. Even after individuals with anorexia nervosa have become accustomed to routinely consuming such foods during treatment in structured settings such as hospital units and day programs, have gained significant weight, and have exhibited substantial psychological improvement, they continue to avoid consuming high-fat food when they can (Walsh, 2013). This behavior is a substantial con- tributor to the high rate of relapse after successful acute treatment in such programs.

The Columbia group has taken a top-down approach in attempting to understand the neural underpinnings of this phenomenon, using emerging knowledge from cognitive neuroscience regarding the acquisition and maintenance of behavior. Specifically, we have suggested that the dieting behavior of anorexia nervosa begins in response to stresses experienced during adolescence and adulthood (Walsh, 2013) and is initially highly rewarding because the resultant weight loss is viewed as a rare accomplishment and evidence of impressive self-control (Steinglass et al., 2012b) and it helps the individual to cope with difficult-to-manage stressors. However, we posit that, over time, as the dieting behavior is repeated and continues to be reinforced, at least intermittently, it becomes engrained via the mechanisms underlying stimulus-response learning; that is, habit formation (Walsh, 2013). This model suggests that, once the behavior has become well established, it engages the dorsal striatum, a striatal subregion associated with habitual behavior (Fig. 2).

To test these hypotheses, we reframed the avoidance of highfat foods characteristic of anorexia nervosa as a choice about what food to eat. We adapted a previously published food choice task (Hare et al., 2009) and expanded it to include photographs of 76 foods, half of which had a high fat content ( $>37 \%$ of calories from fat). The task has three phases and was conducted during fMRI: in the first two phases, subjects are asked to rate each food on "health" and on "taste" using a 5-point Likert scale. From the foods rated neutral by that subject on both health and taste, a "reference food" is randomly chosen. In the third phase of the task (the choice phase), the subject is shown 75 pairs of photographs and asked to indicate which of the two foods they prefer, also using a 5-point Likert scale. The photograph of the reference food is always shown on the left and the 75 other foods are sequentially displayed on the right. At the end of the task, one of the subject's actual choices is randomly selected and that food presented to the subject, who is asked to eat it. On the following day, the subject is asked to select foods from a multi-item buffet and eat these foods for lunch.

We have completed an initial study examining 21 young-adult women hospitalized for treatment of anorexia nervosa and 21 healthy women. As expected, both groups rated the high-fat foods as significantly less healthy than the low-fat foods. On average, the controls rated the high-fat and low-fat foods equally tasty, but the patients rated the high-fat foods less tasty, leading to a significant group $\times$ taste interaction. In the choice phase, patients with anorexia nervosa chose high-fat foods far less frequently than did the controls, leading to a highly significant group $\times$ choice interaction. Furthermore, the proportion of times that patients chose high-fat foods versus the reference food was significantly correlated with the caloric content of the lunch that they chose to consume the following day. These results indicate that the food choice task effectively captures the salient behavioral feature of anorexia nervosa.

Analysis of fMRI data revealed several important findings. First, during the choice phase, individuals with anorexia nervosa engaged the dorsal striatum significantly more than did controls, consistent with our hypothesis. In contrast, there were no differences between groups in activity in the dorsal striatum during the health and taste phases. Second, during the choice phase, there was no difference between groups in activity in the ventral striatum, a subregion associated with goal-directed actions.

The current results are consistent with the possibility that persistent, maladaptive food choice in anorexia nervosa is linked to 


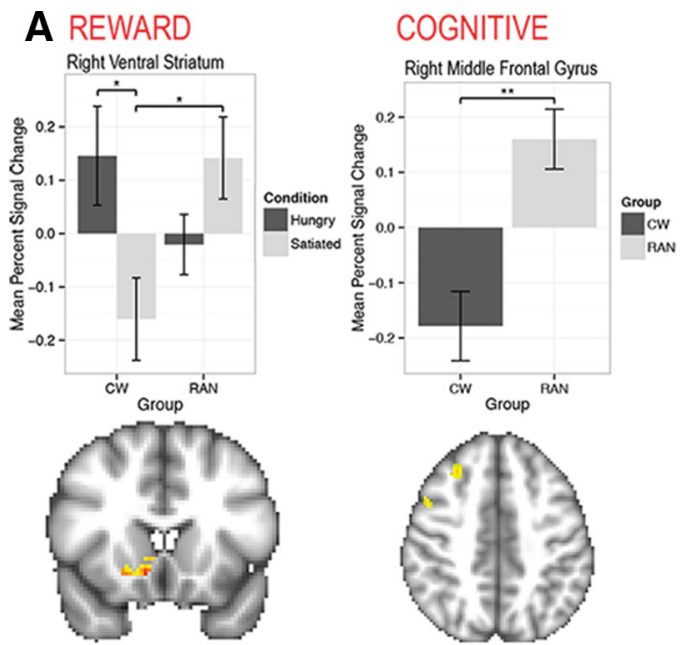

B Healthy Comparison Women : Hunger Condition

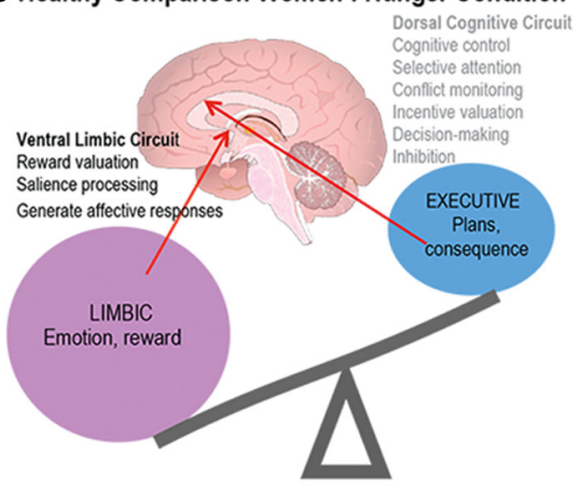

C Healthy Comparison Women : Satiated Condition

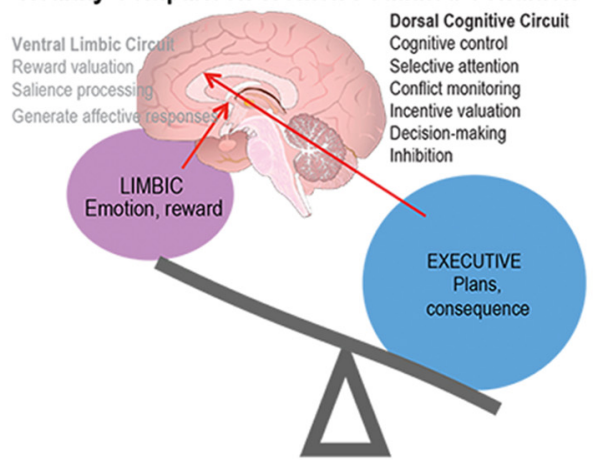

D Women Remitted from Anorexia Nervosa : Hunger and Satiated Conditions

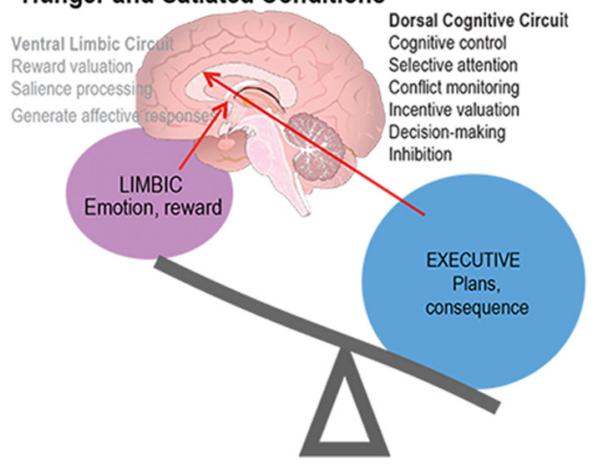

Figure 3. A, Left, Region-of-interest analysis showing that, for "immediate reward valuation" within the right ventral striatum, healthy comparison women (CW) had a greater response when hungry than when satiated; when satiated, remitted anorexia nervosa (RAN) had a greater response than CW. Right, Cognitive-related region-of-interest analysis for the "all activity in the frontostriatal networks crucial for the development of habitual behavior. A similar hypothesis has been proposed regarding substance use and other disorders. The current data suggest that food choice in anorexia nervosa is not guided simply by frontal-striatal activity associated with goal-based, rewarding behaviors and support continued examination of the neural basis of persistent maladaptive food choice in this disorder.

\section{Altered balance between reward and inhibition may favor extremes consumption of food}

Another key question is what factors, such as personality traits, predispose to the development of inappropriate restriction of food intake? The fact that such traits persist after recovery from the eating disorder suggest that they may be predisposing factors for the development of chronic eating disorders. Individuals with anorexia nervosa often report that there is an anxiety-reducing character to dietary restraint and reduced daily caloric intake (Vitousek and Manke, 1994; Kaye et al., 2003; Steinglass et al., 2010), whereas eating stimulates dysphoric mood (Frank and Kaye, 2012).

Symptomatology of individuals with anorexia nervosa suggest potential altered balance among limbic, cognitive, and salience neural circuits. These circuits interact to valuate reward, assess future consequences of one's behavior, and integrate and evaluate reward prediction to guide decisions using cognitive control and inhibition (Phillips et al., 2003). Simply put, patients with anorexia nervosa have a diminished reward and salience response and increased cognitive control and inhibition. For example, they have long been noted to be anhedonic and ascetic, able to sustain self-denial of food and most of the comforts and pleasures in life (Frank et al., 2005). Moreover, patients with anorexia nervosa have an enhanced ability to delay reward (i.e., show less reduction in the value of a monetary reward over time) compared with healthy volunteers (Steinglass et al., 2012a). They also tend to be overcontrolled, overconcerned about consequences, and have high punishment sensitivity in the ill and recovered states (Claes et al., 2006; Harrison et al., 2010; Harrison et al., 2011; Jappe et al., 2011; Matton et al., 2013; Glashouwer et al., 2014).

Data from imaging studies support the argument that enhanced cognitive control and ability to delay reward may help to maintain persistent food restriction. Animal studies show that the ventral striatum processes motivational aspects of stimuli by modulating the influence of limbic inputs on striatal activity (Schultz, 2004; Yin and Knowlton, 2006). In this way, even secondary rewards such as money activate the ventral striatum proportionally to the reward amount or deviation from an expected payoff (Montague et al., 2004). Our group (Wierenga et al., 2015) investigated brain activation during delay discounting in recovered anorexia nervosa when hungry and when satiated (Fig. 3). It is important to emphasize that hunger influences behavioral choice in healthy individuals by increasing the appetitiveness of rewarding stimuli (Goldstone et al., 2009; Wang and Dvorak, 2010; Levy et al., 2013; Tal and Wansink, 2013). Compared with healthy women, recovered anorexia nervosa patients failed to

decisions" analysis. Within the right middle frontal gyrus, RAN responded more strongly than CW for all trials. Error bars represent the SE for each group. ${ }^{*} p=0.05 ;{ }^{* *} p=0.01$. $\boldsymbol{B}-\boldsymbol{D}$, Comparison of ventral limbic and dorsal cognitive circuits in CW showing hunger $(\boldsymbol{B})$ enhances limbic and reduces cognitive activity whereas satiety $(\boldsymbol{C})$ reverses these neural processes. However, in RAN, there is $(\boldsymbol{D})$ reduced limbic and enhanced cognitive function whether hungry or satiated (Wierenga et al., 2015). 
increase activation of reward valuation circuitry when hungry and showed elevated response in cognitive control circuitry regardless of metabolic state (Wierenga et al., 2014). This finding is consistent with our previous studies (Wagner et al., 2007; Wagner et al., 2010; Bischoff-Grethe et al., 2013) and other studies showing that limbic regions are underactive for motivational behavior in ill anorexia nervosa patients (Zastrow et al., 2009). That is, hunger does not make salient stimuli more appetitive in anorexia nervosa. Moreover, difficulties in valuating emotional salience may contribute to inabilities to appreciate the risks inherent in this deadly disorder.

In addition, imaging studies show that altered reward and salience processing is associated with eating pathology. A growing body of research (Kaye et al., 2013) suggests that ill and recovered anorexia nervosa adults have an enhanced anxiety response to anticipated food cues and diminished insula and striatal response to receipt of food (Wagner et al., 2008; Cowdrey et al., 2011; Vocks et al., 2011; Frank et al., 2012; Oberndorfer et al., 2013a, 2013b). A study of response to pain confirms a mismatch between anticipation and objective responses in recovered anorexia nervosa patients (Strigo et al., 2013). That is, there may be a reduced response to "code" reward, but an exaggerated anticipation that is often anxious in nature. An exaggerated response to stimulus cues may be a mean to predict and manage the anxiety elicited by subjectively aversive stimuli, similar to the anticipatory sensitivity linked with stimulus avoidance that is seen in highly anxious individuals (Simmons et al., 2006).

Finally, based on growing evidence from behavioral and imaging studies, individuals with anorexia nervosa could have an impaired ability to identify the emotional significance of a stimulus but increased traffic in neural circuits concerned with planning and consequences, which is associated with anxiety (Wierenga et al., 2014). This overreliance on cognitive brain circuits involved in linking action to outcome may constitute an attempt at "strategic" (as opposed to hedonic) means of responding to reward stimuli.

It is appropriate here to mention the critical implication of 5 -HT systems in anxiety that is prevented when $5-\mathrm{HTR}_{1 \mathrm{~A}}$ is expressed during the early postnatal period (Gross et al., 2002); conversely, the absence of $5-\mathrm{HTR}_{4}$ induces anxiety-like behavior in stressful conditions and leads to decrease in 5-HTR ${ }_{1 \mathrm{~A}}$ levels in the dorsal hippocampus (Compan et al., 2004; Conductier et al., 2006). Interestingly, cocaine administration increased the phosphorylated CREB (pCREB)/CREB ratio in the NAc in wild-type mice but not in 5- $\mathrm{HTR}_{4} \mathrm{KO}$ animals (Fig. 1), suggesting that these receptors enhance CREB phosphorylation. Considering that inhibition of the transcription factor CREB in the NAc has been associated with anxiety-like behavior (Barrot et al., 2005), anorexia induced by stimulation of $5-\mathrm{HTR}_{4}$ in the NAc could favor the "anxiety-reducing character to dietary restraint" (Vitousek and Manke, 1994; Kaye et al., 2003; Steinglass et al., 2010). In contrast, reduced activation of $5-\mathrm{HTR}_{4}$ could enhance anxiety that is provoked by overeating.

\section{Particular molecular mechanism underlies the transition from undereating to overeating}

The mechanism that underlies the transition from undereating to overeating depends on a peculiar property of G-protein coupled receptors (GPCRs) that was described in vitro by Lefkowitz (2007). Like other GPCRs, 5-HTR displays an active form (Gprotein coupled, symbolized by $\mathrm{R}^{*}$ ) and inactive form (G-protein uncoupled, R) in the plasma membrane, mostly described in vitro (Claeysen et al., 2000; Kenakin, 2004), with the unique exception
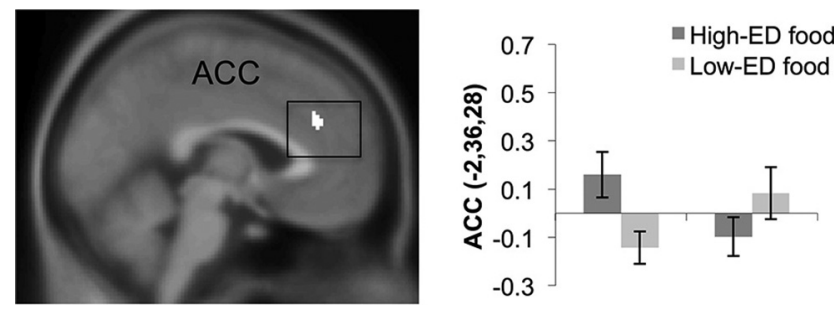

Figure 4. Greater activation in response to high-ED versus low-ED food cues in binge eaters compared with nonbinge eaters in a conjunction of visual and auditory modalities, in the dorsal anterior cingulate cortex ( $\mathrm{AACC}$ ). The bar graph shows $\beta$ estimates for voxels in the $\mathrm{dACC}$ in binge eaters ( $\mathrm{BE}$ ) and nonbinge eaters (non-BE) for high-ED (vs baseline) and low-ED (vs baseline) (Geliebter et al., 2015).

of the MCR4 that have been shown to be constitutively active in vivo (Kim et al., 2008). Some GPCRs then can exhibit an autonomous capacity (or agonist-independent activity called "constitutive activity") to regulate their own intracellular signaling pathways without agonist stimulation. Inhibiting this autonomous capacity of $5-\mathrm{HTR}_{4}$ reduces the activity of their intracellular signaling pathways and stabilizes their $\mathrm{R}$ form. An inverse agonist inhibits the constitutive activity, and displaces the significant amount of $\mathrm{R}^{\star}$ form toward $\mathrm{R}$. Agonists then enrich $\mathrm{R}^{\star}$ whereas inverse agonists stabilize $\mathrm{R}$, and antagonists equilibrate $R / R^{\star}$. However, the physiological consequences of the $R^{\star} / R$ transition ('toggling') was unknown. We found that inactivating totally ("silencing") the NAc-5- $\mathrm{HTR}_{4}$, i.e., injecting a specific inverse agonist of $5-\mathrm{HTR}_{4}$ in the NAc of behaving mice, provoked overeating (competitive antagonist suppressed this response). We hypothesize that the two extremes of the $\mathrm{R}^{\star} / \mathrm{R}$ of $5-\mathrm{HTR}_{4}$, in the NAc correspond to two extremes of feeding patterns: restrictive diet and overeating. Our results indicate that silencing $5-\mathrm{HTR}_{4}$ causes overeating while, as mentioned above, activation of the main signaling pathway (cAMP/PKA) of $5-\mathrm{HTR}_{4}$ in the NAc $\left(R^{\star}\right)$ favors anorexia (Jean et al., 2007; Jean et al., 2012b; Laurent et al., 2012). From $\mathrm{R}^{\star}$ to $\mathrm{R}$, cAMP levels increase then decrease in the NAc. Analyses of downstream molecular signals show that silencing NAc-5-HTR 4 decreases the levels of cAMP, decreases CART and increases the mRNA levels of the orexigenic neuropeptide Y (NPY). siRNA-mediated NPY knock-down in the NAc suppresses overeating induced by silencing $5-\mathrm{HTR}_{4}$ (Compan, 2015).

Consistently, humans with obesity display increased levels of $5-\mathrm{HTR}_{4}$ in the NAc (Haahr et al., 2012), suggesting either an accumulation of $5-\mathrm{HTR}_{4}$ in their inactive state and/or an adaptive compensatory increase in $5-\mathrm{HTR}_{4}$ in response to decreases in 5 -HT contents that are suspected to be lower in humans with obesity (Björntorp, 1995; Strömbom et al., 1996). This is consistent with the inverse correlation between 5-HT and 5- $\mathrm{HTR}_{4}$ contents in rats, pigs, and humans (Compan et al., 1996; Ettrup et al., 2011; Haahr et al., 2014). During one year without bulimic and purging episodes, the levels of 5-HIAA in CSF were higher in patients who were suffering from bulimia than in controls (Kaye et al., 1998). The levels of 5-HIAA are also reduced in CSF of patients with anorexia nervosa, but normalized over the recovery of their body weight (Kaye et al., 1984; Kaye and Weltzin, 1991). Altogether, we suggest that sustaining high constitutive activity of 5 - $\mathrm{HTR}_{4}$ induces persistent anorexia, a corollary to our observation that inhibition of the constitutive activity of 5-HTR 4 triggers excessive food intake. As mentioned above, a maladaptive food choice is associated with changes in the activity of the dorsal, but not the ventral striatum. Whether the absence of increased neural 
activity in the ventral striatum could be associated with low release of 5-HT and high constitutive activity of 5- $\mathrm{HTR}_{4}$ in patients with anorexia nervosa is unknown. The following section provides evidence that, on the other side of the weight spectrum, in individuals with obesity, there is increased brain activity in the dorsal striatum in response to high-calorie food cues.

\section{Differential neural responses to visual and auditory food cues in obesity and binge eating}

We compared fMRI brain activity in response to food cues in obese and lean individuals who had consumed a fixed meal for lunch $3 \mathrm{~h}$ earlier. The obese participants were more likely to show increased brain activity in the putamen (dorsal striatum) and ventral tegmental area (VTA, midbrain), two components of the dopaminergic reward pathway, when shown images (visual cues) or when hearing words (auditory cues) associated with highly energy-dense (ED) food cues such as chocolate cake, ice cream, or french fries compared with low ED foods such as carrots, cucumbers, or apples. That this occurred across different modalities of vision and audition suggests that the effects are independent of sensory input (Geliebter et al., 2006; Carnell et al., 2014). Greater putamen activation in obese versus lean women in response to high-ED compared with low-ED visual stimuli were also noted in another fMRI study (Rothemund et al., 2007). In addition, in a PET study, obese (vs lean) individuals showed greater regional cerebral blood flow in the midbrain in response to a small taste of a liquid meal (DelParigi et al., 2005).

A greater proportion of obese individuals are binge eaters compared with those who are lean (de Zwaan, 2001) and binge eating often precedes obesity (Mussell et al., 1995). When we compared binge eaters with nonbinge eaters, a similar pattern emerged as for comparing obese with lean subjects (Geliebter et al., 2015). That is, there was greater responsively to cues of high$\mathrm{ED}$, more palatable foods than low-ED foods, in this case in the dorsal anterior cingulate (Fig. 4), an area involved in guiding reward-based decision making (Bush et al., 2002). In addition, in a PET study, there was more dopaminergic activity in the dorsal striatum of obese binge eaters than obese nonbinge eaters when a taste of a preferred food was given after oral methylphenidate to enhance dopamine levels (Wang et al., 2011).

After Rouen Y gastric bypass surgery to treat obesity, there was a marked reduction in fMRI activity in the reward areas of the brain associated with dopaminergic pathways [including the VTA and putamen, as well as the dorsolateral prefrontal cortex, ventrolateral and dorsomedial PFC, ventral striatum, and lentiform nucleus (i.e., putamen and pallidum)] in response to high-ED versus low-ED food cues (Ochner et al., 2011; Geliebter, 2013), suggesting that surgery helped to normalize the neural responses in those with obesity. Surgery may induce hormonal changes (e.g., orexin, ghrelin, etc.), which could in turn modify neural activity. The change in neural activity was apparently not due to weight loss per se because it was noted even after statistically controlling for weight change and was also seen in the surgery group only compared with a control group who lost weight by dieting. We have also examined whether the surgery effect differed between those who binge eat and those who do not, and found that after surgery, the brain responses were similarly reduced in both groups for high-energy food cues. This may be because gastric restriction from the surgery virtually prevents binge eating.

\section{Conclusion}

In sum, neural substrates of dependence could interfere with homeostasis and favor maladaptive decision making to not eat or overeat and eventually lead to eating disorders. The neuronal network underlying eating behaviors is part of a larger network implicating reward and decision-making systems that react to environmental cues. Accordingly, environmental changes (i.e., stressors) associated with biological predisposition could alter motivation and adaptive decision making, including the excessive restriction of food intake or types of foods. If adaptive responses to stress depend on the 5-HT system, then eating disorders could emerge when 5-HT neurons reach the limit of their adaptive capacities. We suggest that a predominance of a cortical control reflects an adaptive process to prevent "negative emotional states" when facing an acute stress at the onset of anorexia nervosa, which could be supported by a shared signal foul-up with drugs of abuse. In the face of chronic stress, limits of this adaptive process could "submerge" cortical control and "release the influence of the subcortical areas" such as the NAc (autonomous control without adaptive decisional control), in which uncontrolled oscillating changes in common molecule levels (cAMP, CREB: all controlled by GPCRs) could lead to an anarchic consumption of foods (from anorexia to bulimia and/or binge eating).

\section{References}

Adan RA, Kas MJ (2003) Inverse agonism gains weight. Trends Pharmacol Sci 24:315-321. CrossRef Medline

Amargós-Bosch M, Bortolozzi A, Puig MV, Serrats J, Adell A, Celada P, Toth M, Mengod G, Artigas F (2004) Co-expression and in vivo interaction of serotonin $1 \mathrm{~A}$ and serotonin2A receptors in pyramidal neurons of prefrontal cortex. Cereb Cortex 14:281-299. CrossRef Medline

Amat J, Baratta MV, Paul E, Bland ST, Watkins LR, Maier SF (2005) Medial prefrontal cortex determines how stressor controllability affects behavior and dorsal raphe nucleus. Nat Neurosci 8:365-371. CrossRef Medline

Anderluh MB, Tchanturia K, Rabe-Hesketh S, Treasure J (2003) Childhood obsessive-compulsive personality traits in adult women with eating disorders: defining a broader eating disorder phenotype. Am J Psychiatry 160:242-247. CrossRef Medline

Avena NM (2010) The study of food addiction using animal models of binge eating. Appetite 55:734-737. CrossRef Medline

Barrot M, Wallace DL, Bolaños CA, Graham DL, Perrotti LI, Neve RL, Chambliss H, Yin JC, Nestler EJ (2005) Regulation of anxiety and initiation of sexual behavior by CREB in the nucleus accumbens. Proc Natl Acad Sci U S A 102:8357-8362. CrossRef Medline

Beumont PJ, Arthur B, Russell JD, Touyz SW (1994) Excessive physical activity in dieting disorder patients: proposals for a supervised exercise program. Int J Eat Disord 15:21-36. CrossRef Medline

Bischoff-Grethe A, McCurdy D, Grenesko-Stevens E, Irvine LE, Wagner A, Yau WY, Fennema-Notestine C, Wierenga CE, Fudge JL, Delgado MR, Kaye WH (2013) Albered brain response to reward and punishment in adolescents with anorexia nervosa. Psychiatry Res 214:331-340. Medline

Björntorp P (1995) Neuroendocrine abnormalities in human obesity. Metabolism 44:38-41. CrossRef Medline

Bortolozzi A, Amargós-Bosch M, Toth M, Artigas F, Adell A (2004) In vivo efflux of serotonin in the dorsal raphe nucleus of 5-HT1A receptor knockout mice. J Neurochem 88:1373-1379. Medline

Brockmeyer T, Grosse Holtforth M, Bents H, Herzog W, Friederich HC (2013) Lower body weight is associated with less negative emotions in sad autobiographical memories of patients with anorexia nervosa. Psychiatry Res 210:548-552. CrossRef Medline

Bulik CM, Sullivan PF, Tozzi F, Furberg H, Lichtenstein P, Pedersen NL (2006) Prevalence, heritability, and prospective risk factors for anorexia nervosa. Arch Gen Psychiatry 63:305-312. CrossRef Medline

Bush G, Vogt BA, Holmes J, Dale AM, Greve D, Jenike MA, Rosen BR (2002) Dorsal anterior cingulate cortex: a role in reward-based decision making. Proc Natl Acad Sci U S A 99:523-528. CrossRef Medline

Carnell S, Benson L, Pantazatos SP, Hirsch J, Geliebter A (2014) Amodal 
brain activation and functional connectivity in response to high-energydensity food cues in obesity. Obesity 22:2370-2378. CrossRef Medline

Carter ME, Soden ME, Zweifel LS, Palmiter RD (2013) Genetic identification of a neural circuit that suppresses appetite. Nature 503:111-114. CrossRef Medline

Casper RC (1998) Depression and eating disorders. Depress Anxiety 8:96104. Medline

Casper RC (2006) The 'drive for activity' and "restlessness" in anorexia nervosa: potential pathways. J Affect Disord 92:99-107. CrossRef Medline

Chen JC, Chen PC, Chiang YC (2009) Molecular mechanisms of psychostimulant addiction. Chang Gung Med J 32:148-154. Medline

Claes L, Nederkoorn C, Vandereycken W, Guerrieri R, Vertommen H (2006) Impulsiveness and lack of inhibitory control in eating disorders. Eat Behav 7:196-203. CrossRef Medline

Claeysen S, Sebben M, Bécamel C, Eglen RM, Clark RD, Bockaert J, Dumuis A (2000) Pharmacological properties of 5-Hydroxytryptamine(4) receptor antagonists on constitutively active wild-type and mutated receptors. Mol Pharmacol 58:136-144. Medline

Compan V (2013) Under- to overeating: what role do serotonin receptors play? Future Neurol 8:701-714.

Compan V (2015) Toggling the serotonin 4 receptors between active and silencing state switches motivation from restrictive diet towards overeating. Appetite. In press. CrossRef

Compan V, Daszuta A, Salin P, Sebben M, Bockaert J, Dumuis A (1996) Lesion study of the distribution of serotonin 5-HT4 receptors in rat basal ganglia and hippocampus. Eur J Neurosci 8:2591-2598. CrossRef Medline

Compan V, Zhou M, Grailhe R, Gazzara RA, Martin R, Gingrich J, Dumuis A, Brunner D, Bockaert J, Hen R (2004) Attenuated response to stress and novelty and hypersensitivity to seizures in 5-HT4 receptor knock-out mice. J Neurosci 24:412-419. CrossRef Medline

Conductier G, Dusticier N, Lucas G, Côté F, Debonnel G, Daszuta A, Dumuis A, Nieoullon A, Hen R, Bockaert J, Compan V (2006) Adaptive changes in serotonin neurons of the raphe nuclei in 5-HT(4) receptor knock-out mouse. Eur J Neurosci 24:1053-1062. CrossRef Medline

Corwin RL (2011) The face of uncertainty eats. Curr Drug Abuse Rev 4:174-181. CrossRef Medline

Corwin RL, Avena NM, Boggiano MM (2011) Feeding and reward: perspectives from three rat models of binge eating. Physiol Behav 104:87-97. CrossRef Medline

Couceyro PR, Evans C, McKinzie A, Mitchell D, Dube M, Hagshenas L, White FJ, Douglass J, Richards WG, Bannon AW (2005) Cocaine- and amphetamine-regulated transcript (CART) peptides modulate the locomotor and motivational properties of psychostimulants. J Pharmacol Exp Ther 315:1091-1100. CrossRef Medline

Cowdrey FA, Park RJ, Harmer CJ, McCabe C (2011) Increased neural processing of rewarding and aversive food stimuli in recovered anorexia nervosa. Biol Psychiatry 70:736-743. CrossRef Medline

Czyrak A, Czepiel K, Maćkowiak M, Chocyk A, Wedzony K (2003) Serotonin 5-HT1A receptors might control the output of cortical glutamatergic neurons in rat cingulate cortex. Brain Res 989:42-51. CrossRef Medline

de Zwaan M (2001) Binge eating disorder and obesity. Int J Obes Relat Metab Disord 25:S51-S55. Medline

DelParigi A, Chen K, Salbe AD, Reiman EM, Tataranni PA (2005) Sensory experience of food and obesity: a positron emission tomography study of the brain regions affected by tasting a liquid meal after a prolonged fast. Neuroimage 24:436-443. CrossRef Medline

Doslikova B, Garfield AS, Shaw J, Evans ML, Burdakov D, Billups B, Heisler LK (2013) 5-HT2C receptor agonist anorectic efficacy potentiated by 5-HT1B receptor agonist coapplication: an effect mediated via increased proportion of pro-opiomelanocortin neurons activated. J Neurosci 33: 9800-9804. CrossRef Medline

Ettrup A, Kornum BR, Weikop P, Knudsen GM (2011) An approach for serotonin depletion in pigs: effects on serotonin receptor binding. Synapse 65:136-145. CrossRef Medline

Euston DR, Gruber AJ, McNaughton BL (2012) The role of medial prefrontal cortex in memory and decision making. Neuron 76:1057-1070. CrossRef Medline

Fassino S, Abbate-Daga G, Amianto F, Leombruni P, Boggio S, Rovera GG (2002) Temperament and character profile of eating disorders: a con- trolled study with the Temperament and Character Inventory. Int J Eat Disord 32:412-425. CrossRef Medline

Feng J, Cai X, Zhao J, Yan Z (2001) Serotonin receptors modulate GABA(A) receptor channels through activation of anchored protein kinase $C$ in prefrontal cortical neurons. J Neurosci 21:6502-6511. Medline

Foerde K, Steinglass J, Shohamy D, Walsh BT (2015) Neural mechanisms supporting maladaptive food choices in anorexia nervosa. Nat Neurosci. In press.

Frank GK, Kaye WH (2012) Current status of functional imaging in eating disorders. Int J Eat Disord 45:723-736. CrossRef Medline

Frank GK, Bailer UF, Henry SE, Drevets W, Meltzer CC, Price JC, Mathis CA, Wagner A, Hoge J, Ziolko S, Barbarich-Marsteller N, Weissfeld L, Kaye WH (2005) Increased dopamine D2/D3 receptor binding after recovery from anorexia nervosa measured by positron emission tomography and $\left[{ }^{11} \mathrm{C}\right]$ raclopride. Biol Psychiatry 58:908-912. CrossRef Medline

Frank GK, Reynolds JR, Shott ME, Jappe L, Yang TT, Tregellas JR, O’Reilly RC (2012) Anorexia nervosa and obesity are associated with opposite brain reward response. Neuropsychopharmacology 37:2031-2046. CrossRef Medline

Friederich HC, Herzog W (2011) Cognitive-behavioral flexibility in anorexia nervosa. Curr Top Behav Neurosci 6:111-123. Medline

Garfield AS, Li C, Madara JC, Shah BP, Webber E, Steger JS, Campbell JN, Gavrilova O, Lee CE, Olson DP, Elmquist JK, Tannous BA, Krashes MJ, Lowell BB (2015) A neural basis for melanocortin-4 receptor-regulated appetite. Nat Neurosci 18:863-871. CrossRef Medline

Geliebter A (2013) Neuroimaging of gastric distension and gastric bypass surgery. Appetite 71:459-465. CrossRef Medline

Geliebter A, Ladell T, Logan M, Schneider T, Schweider T, Sharafi M, Hirsch J (2006) Responsivity to food stimuli in obese and lean binge eaters using functional MRI. Appetite 46:31-35. CrossRef Medline

Geliebter A, Benson L, Pantazatos SP, Hirsch J, Carnell S (2015) Greater anterior cingulate activation and connectivity in response to visual and auditory high-calorie food cues in binge eating: preliminary findings. Appetite. In press.

Glashouwer KA, Bloot L, Veensra EM, Franken IH, de Jong PJ (2014) Heightened sensitivity to punishment and reward in anorexia nervosa. Appetite 75:97-102. CrossRef Medline

Godart NT, Flament MF, Lecrubier Y, Jeammet P (2000) Anxiety disorders in anorexia nervosa and bulimia nervosa: co-morbidity and chronology of appearance. Eur Psychiatry 15:38-45. Medline

Goldstone AP, Prechl de Hernandez CG, Beaver JD, Muhammed K, Croese C, Bell G, Durighel G, Hughes E, Waldman AD, Frost G, Bell JD (2009) Fasting biases brain reward systems towards high-calorie foods. Eur J Neurosci 30:1625-1635. CrossRef Medline

Grignaschi G, Mantelli B, Samanin R (1993) The hypophagic effect of restraint stress in rats can be mediated by 5 -HT2 receptors in the paraventricular nucleus of the hypothalamus. Neurosci Lett 152:103-106. CrossRef Medline

Gross C, Zhuang X, Stark K, Ramboz S, Oosting R, Kirby L, Santarelli L, Beck S, Hen R (2002) Serotonin1A receptor acts during development to establish normal anxiety-like behaviour in the adult. Nature 416:396-400. CrossRef Medline

Haahr ME, Fisher PM, Jensen CG, Frokjaer VG, Mahon BM, Madsen K, Baaré WF, Lehel S, Norremolle A, Rabiner EA, Knudsen GM (2014) Central 5-HT4 receptor binding as biomarker of serotonergic tonus in humans: a [(11)C]SB207145 PET study. Mol Psychiatry 19:427-432. CrossRef Medline

Haahr ME, Rasmussen PM, Madsen K, Marner L, Ratner C, Gillings N, Baaré WF, Knudsen GM (2012) Obesity is associated with high serotonin 4 receptor availability in the brain reward circuitry. Neuroimage 61:884888. CrossRef Medline

Haj-Dahmane S, Hamon M, Lanfumey L (1991) K+ channel and 5-hydroxytryptamine1A autoreceptor interactions in the rat dorsal raphe nucleus: an in vitro electrophysiological study. Neuroscience 41:495-505. CrossRef Medline

Haleem DJ, Jabeen B, Parveen T (1998) Inhibition of restraint-induced anorexia by injected tryptophan. Life Sci 63:PL205-PL212. Medline

Hardaway JA, Crowley NA, Bulik CM, Kash TL (2015) Integrated circuits and molecular components for stress and feeding: implications for eating disorders. Genes Brain Behav 14:85-97. CrossRef Medline

Hare TA, Camerer CF, Rangel A (2009) Self-control in decision-making 
involves modulation of the vmPFC valuation system. Science 324:646648. CrossRef Medline

Harrison A, O'Brien N, Lopez C, Treasure J (2010) Sensitivity to reward and punishment in eating disorders. Psychiatry Res 177:1-11. CrossRef Medline

Harrison A, Treasure J, Smillie LD (2011) Approach and avoidance motivation in eating disorders. Psychiatry Res 188:396-401. CrossRef Medline

Heisler LK, Cowley MA, Tecott LH, Fan W, Low MJ, Smart JL, Rubinstein M, Tatro JB, Marcus JN, Holstege H, Lee CE, Cone RD, Elmquist JK (2002) Activation of central melanocortin pathways by fenfluramine. Science 297:609-611. CrossRef Medline

Higgins GA, Sellers EM, Fletcher PJ (2013) From obesity to substance abuse: therapeutic opportunities for 5-HT2C receptor agonists. Trends Pharmacol Sci 34:560-570. CrossRef Medline

Hoebel BG (1997) Neuroscience and appetitive behavior research: 25 years. Appetite 29:119-133. CrossRef Medline

Howell LL, Cunningham KA (2015) Serotonin 5-HT2 receptor interactions with dopamine function: implications for therapeutics in cocaine use disorder. Pharmacol Rev 67:176-197. Medline

Jappe LM, Frank GK, Shott ME, Rollin MD, Pryor T, Hagman JO, Yang TT, Davis E (2011) Heightened sensitivity to reward and punishment in anorexia nervosa. Int J Eat Disord 44:317-324. CrossRef Medline

Jean A, Conductier G, Manrique C, Bouras C, Berta P, Hen R, Charnay Y, Bockaert J, Compan V (2007) Anorexia induced by activation of serotonin 5-HT4 receptors is mediated by increases in CART in the nucleus accumbens. Proc Natl Acad Sci U S A 104:16335-16340. CrossRef Medline

Jean A, Laurent L, Doly S, Dusticier N, Neve R, Maroteaux L, Nieoullon A, Compan V (2012a) Decision-making to eat after stress depends on the serotonin 4 and $1 \mathrm{~A}$ receptors in the medial prefrontal cortex and dorsal raphé. Presented at the 42th Annual Meeting, Society for Neuroscience, Hot Topic Research. New Orleans, USA.

Jean A, Laurent L, Bockaert J, Charnay Y, Dusticier N, Nieoullon A, Barrot M, Neve R, Compan V (2012b) The nucleus accumbens 5-HTR(4)-CART pathway ties anorexia to hyperactivity. Transl Psychiatry 2:e203. CrossRef Medline

Kaye WH, Weltzin TE (1991) Serotonin activity in anorexia and bulimia nervosa: relationship to the modulation of feeding and mood. J Clin Psychiatry 52:41-48. Medline

Kaye WH, Ebert MH, Raleigh M, Lake R (1984) Abnormalities in CNS monoamine metabolism in anorexia nervosa. Arch Gen Psychiatry 41: 350-355. CrossRef Medline

Kaye WH, Greeno CG, Moss H, Fernstrom J, Fernstrom M, Lilenfeld LR, Weltzin TE, Mann JJ (1998) Alterations in serotonin activity and psychiatric symptoms after recovery from bulimia nervosa. Arch Gen Psychiatry 55:927-935. CrossRef Medline

Kaye WH, Bulik CM, Thornton L, Barbarich N, Masters K (2004) Comorbidity of anxiety disorders with anorexia and bulimia nervosa. Am J Psychiatry 161:2215-2221. CrossRef Medline

Kaye WH, Fudge JL, Paulus M (2009) New insights into symptoms and neurocircuit function of anorexia nervosa. Nat Rev Neurosci 10:573-584. CrossRef Medline

Kaye W, Strober M, Klump KL (2003) Neurobiology of eating disorders. New York: OUP.

Kaye WH, Wierenga CE, Bailer UF, Simmons AN, Wagner A, BischoffGrethe A (2013) Does a shared neurobiology for foods and drugs of abuse contribute to extremes of food ingestion in anorexia and bulimia nervosa? Biol Psychiatry 73:836-842. CrossRef Medline

Kenakin T (2004) Efficacy as a vector: the relative prevalence and paucity of inverse agonism. Mol Pharmacol 65:2-11. CrossRef Medline

Kim DH, Shin SW, Baik JH (2008) Role of third intracellular loop of the melanocortin 4 receptor in the regulation of constitutive activity. Biochem Biophys Res Commun 365:439-445. CrossRef Medline

Koob GF, Nestler EJ (1997) The neurobiology of drug addiction. J Neuropsychiatry Clin Neurosci 9:482-497. CrossRef Medline

Kumar KK, Tung S, Iqbal J (2010) Bone loss in anorexia nervosa: leptin, serotonin, and the sympathetic nervous system. Ann N Y Acad Sci 1211: 51-65. CrossRef Medline

Kupfermann I (1991) Hypothalamus and limbic system: peptidergic neurons, homeostasis and emotional behavior. In: Principles of neural science, Ed 3 (Kandel E, Schwartz J, Jessel T, eds), pp. 738-749. Maidenhead, UK: McGraw-Hill Education.

Laurent L, Jean A, Manrique C, Najimi M, Chigr F, Compan V (2012) An- orexia and drugs of abuse abnormally suppress appetite, the result of a shared molecular signal foul-up. In: Animal model of eating disorders (Avena N, ed), pp 319-331. New York: Humana.

Lee HS, Kim MA, Valentino RJ, Waterhouse BD (2003) Glutamatergic afferent projections to the dorsal raphe nucleus of the rat. Brain Res 963: 57-71. CrossRef Medline

Lefkowitz RJ (2007) Seven transmembrane receptors: a brief personal retrospective. Biochem Biophys Acta 1768:748-755. CrossRef Medline

Levy DJ, Thavikulwat AC, Glimcher PW (2013) State dependent valuation: the effect of deprivation on risk preferences. PLoS One 8:e53978. CrossRef Medline

Lubrano-Berthelier C, Cavazos M, Dubern B, Shapiro A, Stunff CL, Zhang S, Picart F, Govaerts C, Froguel P, Bougneres P, Clement K, Vaisse C (2003) Molecular genetics of human obesity-associated MC4R mutations. Ann N Y Acad Sci 994:49-57. CrossRef Medline

Lucas G, Debonnel G (2002) 5-HT4 receptors exert a frequency-related facilitatory control on dorsal raphe nucleus 5-HT neuronal activity. Eur J Neurosci 16:817-822. CrossRef Medline

Lucas G, Compan V, Charnay Y, Neve RL, Nestler EJ, Bockaert J, Barrot M, Debonnel G (2005) Frontocortical 5-HT4 receptors exert positive feedback on serotonergic activity: viral transfections, subacute and chronic treatments with 5-HT4 agonists. Biol Psychiatry 57:918-925. CrossRef Medline

Matton A, Goossens L, Braet C, Vervaet M (2013) Punishment and reward sensitivity: are naturally occurring clusters in these traits related to eating and weight problems in adolescents? Eur Eat Disord Rev 21:184-194. CrossRef Medline

Micali N, Solmi F, Horton NJ, Crosby RD, Eddy KT, Calzo JP, Sonneville KR, Swanson SA, Field AE (2015) Adolescent eating disorders predict psychiatric, high-risk behaviors and weight outcomes in young adulthood. J Am Acad Child Adolesc Psychiatry 54:652-659.e1. Medline

Miquel MC, Doucet E, Riad M, Adrien J, Vergé D, Hamon M (1992) Effect of the selective lesion of serotoninergic neurons on the regional distribution of 5-HT1A receptor mRNA in the rat brain. Brain Res Mol Brain Res 14:357-362. CrossRef Medline

Montague PR, Hyman SE, Cohen JD (2004) Computational roles for dopamine in behavioural control. Nature 431:760-767. CrossRef Medline

Morley JE, Levine AS, Rowland NE (1983) Minireview. Stress induced eating. Life Sci 32:2169-2182. CrossRef Medline

Mussell MP, Mitchell JE, Weller CL, Raymond NC, Crow SJ, Crosby RD (1995) Onset of binge eating, dieting, obesity, and mood disorders among subjects seeking treatment for binge eating disorder. Int J Eat Disord 17:395-401. CrossRef Medline

Nestler EJ (2004) Historical review: Molecular and cellular mechanisms of opiate and cocaine addiction. Trends Pharmacol Sci 25:210-218. CrossRef Medline

Nestler EJ (2005) The neurobiology of cocaine addiction. Sci Pract Perspect 3:4-10. CrossRef Medline

Nestler EJ (2013) Treating the brain deep down: brain surgery for anorexia nervosa? Nat Med 19:678-679. CrossRef Medline

Oberndorfer TA, Frank GK, Simmons AN, Wagner A, McCurdy D, Fudge JL, Yang TT, Paulus MP, Kaye WH (2013a) Altered insula response to sweet taste processing after recovery from anorexia and bulimia nervosa. Am J Psychiatry 170:1143-1151. Medline

Oberndorfer T, Simmons A, McCurdy D, Strigo I, Matthews S, Yang T, Irvine Z, Kaye W (2013b) Greater anterior insula activation during anticipation of food images in women recovered from anorexia nervosa versus controls. Psychiatry Res 214:132-141. CrossRef Medline

Ochner CN, Kwok Y, Conceição E, Pantazatos SP, Puma LM, Carnell S, Teixeira J, Hirsch J, Geliebter A (2011) Selective reduction in neural responses to high calorie foods following gastric bypass surgery. Ann Surg 253:502-507. CrossRef Medline

Pandit R, de Jong JW, Vanderschuren LJ, Adan RA (2011) Neurobiology of overeating and obesity: the role of melanocortins and beyond. Eur J Pharmacol 660:28-42. CrossRef Medline

Papadopoulos FC, Ekbom A, Brandt L, Ekselius L (2009) Excess mortality, causes of death and prognostic factors in anorexia nervosa. Br J Psychiatry 194:10-17. CrossRef Medline

Penas-Cazorla R, Vilaro MT (2014) Serotonin 5-HT receptors and forebrain cholinergic system: receptor expression in identified cell populations. Brain Struct Funct. In press.

Peyron C, Petit JM, Rampon C, Jouvet M, Luppi PH (1998) Forebrain af- 
ferents to the rat dorsal raphe nucleus demonstrated by retrograde and anterograde tracing methods. Neuroscience 82:443-468. Medline

Phillips M, Drevets W, Rauch S, Lane R (2003) Neurobiology of emotion perception I: The neural basis of normal emotion perception Biol Psych 54:504-514.

Picciotto MR (2008) Galanin and addiction. Cell Mol Life Sci 65:18721879. CrossRef Medline

Pompeiano M, Palacios JM, Mengod G (1992) Distribution and cellular localization of mRNA coding for 5-HT1A receptor in the rat brain: correlation with receptor binding. J Neurosci 12:440-453. Medline

Pratt WE, Blackstone K, Connolly ME, Skelly MJ (2009) Selective serotonin receptor stimulation of the medial nucleus accumbens causes differential effects on food intake and locomotion. Behav Neurosci 123:1046-1057. CrossRef Medline

Reddy IA, Stanwood GD, Galli A (2014) Moving beyond energy homeostasis: new roles for glucagon-like peptide-1 in food and drug reward. Neurochem Int 73:49-55. CrossRef Medline

Robbins TW (2005) Controlling stress: how the brain protects itself from depression. Nat Neurosci 8:261-262. CrossRef Medline

Rocha BA, Scearce-Levie K, Lucas JJ, Hiroi N, Castanon N, Crabbe JC, Nestler EJ, Hen R (1998) Increased vulnerability to cocaine in mice lacking the serotonin-1B receptor. Nature 393:175-178. CrossRef Medline

Rocha BA, Goulding EH, O'Dell LE, Mead AN, Coufal NG, Parsons LH, Tecott LH (2002) Enhanced locomotor, reinforcing, and neurochemical effects of cocaine in serotonin 5-hydroxytryptamine 2C receptor mutant mice. J Neurosci 22:10039-10045. Medline

Rogge GA, Jones DC, Green T, Nestler E, Kuhar MJ (2009) Regulation of CART peptide expression by CREB in the rat nucleus accumbens in vivo. Brain Res 1251:42-52. CrossRef Medline

Rothemund Y, Preuschhof C, Bohner G, Bauknecht HC, Klingebiel R, Flor H, Klapp BF (2007) Differential activation of the dorsal striatum by highcalorie visual food stimuli in obese individuals. Neuroimage 37:410-421. CrossRef Medline

Rowland NE, Antelman SM (1976) Stress-induced hyperphagia and obesity in rats: a possible model for understanding human obesity. Science 191: 310-312. CrossRef Medline

Salamone JD, Correa M (2013) Dopamine and food addiction: lexicon badly needed. Biol Psychiatry 73:e15-24. CrossRef Medline

Santana N, Bortolozzi A, Serrats J, Mengod G, Artigas F (2004) Expression of serotonin $1 \mathrm{~A}$ and serotonin2A receptors in pyramidal and GABAergic neurons of the rat prefrontal cortex. Cereb Cortex 14:1100-1109. CrossRef Medline

Schultz W (2004) Neural coding of basic reward terms of animal learning theory, game theory, microeconomics and behavioural ecology. Curr Opin Neurobiol 14:139-147. Medline

Schwartz MW, Woods SC, Porte D Jr, Seeley RJ, Baskin DG (2000) Central nervous system control of food intake. Nature 404:661-671. Medline

Sesack SR, Deutch AY, Roth RH, Bunney BS (1989) Topographical organization of the efferent projections of the medial prefrontal cortex in the rat: an anterograde tract-tracing study with Phaseolus vulgaris leucoagglutinin. J Comp Neurol 290:213-242. CrossRef Medline

Shibasaki T, Yamauchi N, Kato Y, Masuda A, Imaki T, Hotta M, Demura H, Oono H, Ling N, Shizume K (1988) Involvement of corticotropinreleasing factor in restraint stress-induced anorexia and reversion of the anorexia by somatostatin in the rat. Life Sci 43:1103-1110. CrossRef Medline

Shimizu N, Oomura Y, Kai Y (1989) Stress-induced anorexia in rats mediated by serotonergic mechanisms in the hypothalamus. Physiol Behav 46:835-841. CrossRef Medline

Simmons A, Strigo I, Matthews SC, Paulus MP, Stein MB (2006) Anticipation of aversive visual stimuli is associated with increased insula activation in anxiety-prone subjects. Biol Psychiatry 60:402-409. CrossRef Medline

Solway A, Botvinick MM (2012) Goal-directed decision making as probabilistic inference: a computational framework and potential neural correlates. Psychol Rev 119:120-154. CrossRef Medline

Sprouse JS, Aghajanian GK (1987) Electrophysiological responses of serotoninergic dorsal raphe neurons to 5-HT1A and 5-HT1B agonists. Synapse 1:3-9. CrossRef Medline

Srinivasan S, Lubrano-Berthelier C, Govaerts C, Picard F, Santiago P, Conklin BR, Vaisse C (2004) Constitutive activity of the melanocortin-4 receptor is maintained by its $\mathrm{N}$-terminal domain and plays a role in energy homeostasis in humans. J Clin Invest 114:1158-1164. CrossRef Medline
Steinglass J, Foerde K (2015) How does anorexia nervosa become resistant to change? In: Managing severe and enduring anorexia nervosa (Touyz $\mathrm{S}$, Le Grange D, Hay P, Lacey H, eds). London: Routledge.

Steinglass JE, Sysko R, Mayer L, Berner LA, Schebendach J, Wang Y, Chen H, Albano AM, Simpson HB, Walsh BT (2010) Pre-meal anxiety and food intake in anorexia nervosa. Appetite 55:214-218. CrossRef Medline

Steinglass JE, Figner B, Berkowitz S, Simpson HB, Weber EU, Walsh BT (2012b) Increased capacity to delay reward in anorexia nervosa. J Int Neuropsychol Soc 18:773-780. CrossRef Medline

Steinglass J, Albano AM, Simpson HB, Carpenter K, Schebendach J, Attia E (2012a) Fear of food as a treatment target: exposure and response prevention for anorexia nervosa in an open series. Int J Eat Disord 45:615621. CrossRef Medline

Stone EA, Trullas R, Platt JE (1984) The effect of acute and chronic administration of desmethylimipramine on responses to stress in rats. Prog Neuropsychopharmacol Biol Psychiatry 8:587-592. CrossRef Medline

Strigo IA, Matthews SC, Simmons AN, Oberndorfer T, Klabunde M, Reinhardt LE, Kaye WH (2013) Altered insula activation during pain anticipation in individuals recovered from anorexia nervosa: evidence of interocetive dysregulation. Int J Eat Disord 46:23-33. CrossRef Medline

Strömbom U, Krotkiewski M, Blennow K, Månsson JE, Ekman R, Björntorp $P$ (1996) The concentrations of monoamine metabolites and neuropeptides in the cerebrospinal fluid of obese women with different body fat distribution. Int J Obes Relat Metab Disord 20:361-368. Medline

Tal A, Wansink B (2013) Fattening fasting: hungry grocery shoppers buy more calories, not more food. JAMA Intern Med 173:1146-1148. CrossRef Medline

Van Bockstaele EJ, Biswas A, Pickel VM (1993) Topography of serotonin neurons in the dorsal raphe nucleus that send axon collaterals to the rat prefrontal cortex and nucleus accumbens. Brain Res 624:188-198. CrossRef Medline

van den Heuvel JK, Furman K, Gumbs MC, Eggels L, Opland DM, Land BB, Kolk SM, S Narayanan N, Fliers E, Kalsbeek A, DiLeone RJ, la Fleur SE (2015) Neuropeptide Y activity in the nucleus accumbens modulates feeding behavior and neuronal activity. Biol Psychiatry 77:633-641. CrossRef Medline

van den Heuvel OA, Veltman DJ, Groenewegen HJ, Witter MP, Merkelbach J, Cath DC, van Balkom AJ, van Oppen P, van Dyck R (2005) Disorderspecific neuroanatomical correlates of attentional bias in obsessivecompulsive disorder, panic disorder, and hypochondriasis. Arch Gen Psychiatry 62:922-933. CrossRef Medline

Vertes RP (2004) Differential projections of the infralimbic and prelimbic cortex in the rat. Synapse 51:32-58. CrossRef Medline

Vitousek K, Manke F (1994) Personality variables and disorders in anorexia nervosa and bulimia nervosa. J Abnorm Psychol 103:137-147. CrossRef Medline

Vocks S, Herpertz S, Rosenberger C, Senf W, Gizewski ER (2011) Effects of gustatory stimulation on brain activity during hunger and satiety in females with restricting-type anorexia nervosa: an fMRI study. J Psychiatr Res 45:395-403. CrossRef Medline

Wagner A, Aizenstein H, Venkatraman VK, Fudge J, May JC, Mazurkewicz L, Frank GK, Bailer UF, Fischer L, Nguyen V, Carter C, Putnam K, Kaye WH (2007) Altered reward processing in women recovered from anorexia nervosa. Am J Psychiatry 164:1842-1849. CrossRef Medline

Wagner A, Aizenstein H, Mazurkewicz L, Fudge J, Frank GK, Putnam K, Bailer UF, Fischer L, Kaye WH (2008) Altered insula response to a taste stimulus in individuals recovered from restricting-type anorexia nervosa. Neuropsychopharmacology 33:513-523. CrossRef Medline

Wagner A, Aizenstein H, Venkatraman VK, Bischoff-Grethe A, Fudge J, May JC, Frank GK, Bailer UF, Fischer L, Putnam K, Kaye WH (2010) Altered striatal response to reward in bulimia nervosa after recovery. Int J Eat Disord 43:289-294. CrossRef Medline

Walsh BT (2011) The importance of eating behavior in eating disorders. Physiol Behav 104:525-529. CrossRef Medline

Walsh BT (2013) The enigmatic persistence of anorexia nervosa. Am J Psychiatry 170:477-484. CrossRef Medline

Wang GJ, Geliebter A, Volkow ND, Telang FW, Logan J, Jayne MC, Galanti K, Selig PA, Han H, Zhu W, Wong CT, Fowler JS (2011) Enhanced striatal dopamine release during food stimulation in binge eating disorder. Obesity 19:1601-1608. CrossRef Medline 
Wang SW (2002) Effects of restraint stress and serotonin on macronutrient selection: a rat model of stress-induced anorexia. Eat Weight Disord 7: 23-31. CrossRef Medline

Wang XT, Dvorak RD (2010) Sweet future: fluctuating blood glucose levels affect future discounting. Psychol Sci 21:183-188. CrossRef Medline

Wierenga CE, Bischoff-Grethe A, Melrose AJ, Irvine Z, Torres L, Bailer UF, Simmons A, Fudge JL, McClure SM, Ely A, Kaye WH (2015) Hunger does not motivate reward in women remitted from anorexia nervosa. Biol Psychiatry 77:642-652. CrossRef Medline

Wierenga CE, Ely A, Bischoff-Grethe A, Bailer UF, Simmons AN, Kaye WH (2014) Are extremes of consumption in eating disorders related to an altered balance between reward and inhibition? Front Behav Neurosci 8:410. Medline

Wikler A (1961) On the nature of addiction and habituation. Br J Addict Alcohol Other Drugs 57:73-79. CrossRef

Woolley JD, Lee BS, Kim B, Fields HL (2007) Opposing effects of intranucleus accumbens mu and kappa opioid agonists on sensory specific satiety. Neuroscience 146:1445-1452. CrossRef Medline
Yadav VK, Oury F, Suda N, Liu ZW, Gao XB, Confavreux C, Klemenhagen KC, Tanaka KF, Gingrich JA, Guo XE, Tecott LH, Mann JJ, Hen R, Horvath TL, Karsenty G (2009) A serotonin-dependent mechanism explains the leptin regulation of bone mass, appetite, and energy expenditure. Cell 138:976-989. CrossRef Medline

Yadav VK, Oury F, Tanaka KF, Tanaka K, Thomas T, Wang Y, Cremers S, Hen R, Krust A, Chambon P, Karsenty G (2011) Leptin-dependent serotonin control of appetite: temporal specificity, transcriptional regulation, and therapeutic implications. J Exp Med 208:41-52. CrossRef Medline

Yin H, Knowlton B (2006) The role of the basal ganglia in habit formation. Nat Rev Neurosci 7:464-476. CrossRef Medline

Zastrow A, Kaiser S, Stippich C, Walther S, Herzog W, Tchanturia K, Belger A, Weisbrod M, Treasure J, Friederich HC (2009) Neural correlates of impaired cognitive-behavioral flexibility in anorexia nervosa. Am J Psychiatry 166:608-616. CrossRef Medline

Zhang M, Kelley AE (1997) Opiate agonists microinjected into the nucleus accumbens enhance sucrose drinking in rats. Psychopharmacology (Berl) 132:350-360. CrossRef Medline 